\title{
Nurse egg consumption and intracapsular development in the common whelk Buccinum undatum (Linnaeus 1758)
}

\author{
Kathryn E. Smith $\cdot$ Sven Thatje
}

Received: 29 November 2011/Revised: 12 April 2012/ Accepted: 17 April 2012/Published online: 3 May 2012

(C) Springer-Verlag and AWI 2012

\begin{abstract}
Intracapsular development is common in marine gastropods. In many species, embryos develop alongside nurse eggs, which provide nutrition during ontogeny. The common whelk Buccinum undatum is a commercially important North Atlantic shallow-water gastropod. Development is intracapsular in this species, with individuals hatching as crawling juveniles. While its reproductive cycle has been well documented, further work is necessary to provide a complete description of encapsulated development. Here, using $B$. undatum egg masses from the south coast of England intracapsular development at $6{ }^{\circ} \mathrm{C}$ is described. Number of eggs, veligers and juveniles per capsule are compared, and nurse egg partitioning, timing of nurse egg consumption and intracapsular size differences through development are discussed. Total development took between 133 and 140 days, over which 7 ontogenetic stages were identified. The number of both eggs and veligers were significantly related to capsule volume, with approximately $1 \%$ of eggs developing per capsule. Each early veliger consumed nurse eggs rapidly over just 3-7 days. Within each capsule, initial development was asynchronous, but it became synchronous during the veliger stage. No evidence for cannibalism was found during development, but large size differences between embryos developing within each capsule were observed, and occasionally 'empty' veligers were seen, which had not successfully consumed any nurse eggs. These results indicate a high level of competition for nurse eggs within
\end{abstract}

Communicated by Martin Thiel.

K. E. Smith $(\bowtie) \cdot S$. Thatje

Ocean and Earth Science, University of Southampton,

National Oceanography Centre, Southampton,

European Way, Southampton SO14 3ZH, UK

e-mail: kathryn.smith@noc.soton.ac.uk each capsule during development in the common whelk. The initial differences observed in nurse egg uptake may affect individual predisposition in later life.

Keywords Intracapsular development - Buccinum undatum · Nurse egg partitioning · Competition . Reproduction

\section{Introduction}

Many marine gastropods undergo intracapsular development inside egg capsules (Thorson 1950; Natarajan 1957; D'Asaro 1970; Fretter and Graham 1985). Embryos develop within the protective walls of a capsule that safeguards against factors such as physical stress, predation, infection and salinity changes (Thorson 1950; Pechenik 1983, 1999; Strathmann 1985; Rawlings 1995, 1999). Periods of encapsulation vary; some species are released as veligers and undergo a planktonic stage before reaching adult life (mixed development), while others display direct development, hatching from capsules as crawling juveniles (Natarajan 1957; D’Asaro 1970; Pechenik 1979). When direct development occurs, embryos are often accompanied in a capsule by nurse eggs, nondeveloping food eggs, which provide nutrition during development (Thorson 1950; Spight 1976b; Rivest 1983; Lahbib et al. 2010). These are usually indistinguishable from embryos in the very early stage of ontogeny and are consumed during development, potentially increasing size of juveniles at hatching (Thorson 1950). In some species, nutrition may also be provided by intracapsular fluid or protein from capsule walls (Bayne 1968; Stöckmann-Bosbach 1988; Moran 1999; Ojeda and Chaparro 2004).

Generally speaking, nurse egg consumption occurs over a period of several weeks or months. It commences some 
weeks into development as embryos form, and nurse eggs are then slowly consumed throughout much of development (Chaparro and Paschke 1990; Ilano et al. 2004; Lahbib et al. 2010). The number of nurse eggs consumed during this period varies across species. Ratios range from 1.7 nurse eggs per embryo in the Pacific shallow-water muricid Acanthinucella spirata (Spight 1976a), to between 50,000 and 100,000 nurse eggs per embryo in the North Atlantic deep-sea buccinid Volutopsius norwegicus (Thorson 1950). Often, within a species, the nurse egg to embryo ratio varies from capsule to capsule within one clutch (Thorson 1950; Spight 1976a). For example, Rivest (1983) found this ratio in the buccinid Lirabuccinum dirum to vary from 11 to 46 across capsules. Similar differences have been reported for other gastropods (Natarajan 1957; Spight 1976a). Within a capsule however, there is usually little variation in the number of nurse eggs ingested by each embryo, with all embryos generally being equal in their ability to consume. Any differences observed are minimal, and juveniles hatching from each capsule are normally of a very similar size (Natarajan 1957; Spight 1976a; Rivest 1983; Chaparro and Paschke 1990; Chaparro et al. 1999; Lloyd and Gosselin 2007). Large size differences amongst capsulemates are unusual, but have been reported in some species of muricid gastropod (Gallardo 1979; González and Gallardo 1999; Cumplido et al. 2011). In gastropods, the number of eggs inside a capsule is usually positively related to capsule size. Within a species, larger capsules hold more eggs and more developing embryos (Gallardo 1979; Pechenik et al. 1984; Miloslavich and Dufresne 1994). The relationship between capsule size and number of eggs (including nurse eggs) has, however, previously been shown to be stronger than the relationship between capsule size and number of developing embryos (Spight 1976b). In some cases, the number of developing embryos within a capsule has been found to be independent of capsule volume. This suggests that embryos are distributed at random, while nurse eggs are regularly placed amongst capsules (Rivest 1983; Chaparro et al. 1999).

Intracapsular development and nurse egg and embryo partitioning have been investigated in several species of marine gastropod (Natarajan 1957; D'Asaro 1970; Spight 1976a; Rivest 1983; Cumplido et al. 2011). While some attempts have been made to examine encapsulated development in the common whelk Buccinum undatum (Portmann 1925; Fretter and Graham 1985; Nasution 2003), it has not yet been fully described. Nasution (2003) gives the most indepth account of development to date, but his descriptions are incomplete and his reports of nurse egg consumption do not match our observations. Descriptions from Portmann (1925) better fit our observations but lack detail. There are also gaps in the current literature, and very limited knowledge exists on nurse egg partitioning and intracapsular embryo size ranges through development. The common whelk is a scavenger found widespread in coastal areas in the North Atlantic. It is generally found from the shallow subtidal down to a few hundred metres of water depth (Valentinsson et al. 1999; Valentinsson 2002; Rosenberg 2009), with a latitudinal range from $38^{\circ} \mathrm{N}$ to $79^{\circ} \mathrm{N}$ spanning the North Atlantic and Arctic Oceans (OBIS http://iobis.org/ mapper/?taxon=Buccinumundatum). Buccinum undatum is an important commercial species, providing locally valuable fisheries in several areas around the North Atlantic including the UK, the USA and Canada (Hancock 1967; Morel and Bossy 2004). It has been suggested as a good candidate for aquaculture (Nasution and Roberts 2004) and globally, demand for it is continuously increasing (Department of Marine Resources www.maine.gov/dmr/rm/whelks.html). Its reproductive cycle has been well documented across its range (Hancock 1967; Martel et al. 1986a, b; Kideys et al. 1993; Valentinsson 2002). Females group to deposit small creamy coloured spherical egg capsules (Martel et al. 1986a). Each lays approximately $80-150$, which collectively can create large egg masses of hundreds to thousands of capsules (Fretter and Graham 1985; Valentinsson 2002). The time of year for spawning varies in this species across its distribution. In coastal waters of the UK, egg capsules are laid during the autumn and winter months (predominantly late November-January) as annual water temperatures drop below $9{ }^{\circ} \mathrm{C}$ (Hancock 1967; Kideys et al. 1993). In the northwest Atlantic, egg laying instead takes place in spring (late May to mid July) as water temperatures warm (approximately $2-3{ }^{\circ} \mathrm{C}$ ) (Martel et al. 1986a). Intracapsular development takes between 2.5 and 9 months across the species range (Fretter and Graham 1985; Martel et al. 1986a; Kideys et al. 1993; Nasution 2003). Given the widespread distribution of $B$. undatum, its current commercial importance and its potential as a future candidate for aquaculture, it is important to understand fully the development in this species.

Here, we examine intracapsular development in $B$. undatum using a population from the south coast of England, at the southern end of the species distribution. Number of eggs and number of developing veligers and juveniles are examined through development. Ontogenetic stages are described in detail including nurse egg partitioning, nurse egg consumption and intracapsular ranges in embryo sizes.

\section{Materials and methods}

Embryonic development

In order to study the intracapsular development in B. undatum, 150 adults were collected from Viviers UK in late November 2009 (www.fishmarketportsmouth.co.uk). 
Adults were originally gathered from the Solent, UK $\left(50^{\circ} 39^{\prime} \mathrm{N}, 001^{\circ} 37^{\prime} \mathrm{W}\right)$ from approximately $15 \mathrm{~m}$ water depth by Viviers using whelk traps. They were taken to the aquarium at the National Oceanography Centre, Southampton, and placed in a large outdoor tank with continuous seawater flow through. Whelks were fed scrap fish ad libitum 3 times a week, and the tank was checked daily for laying activity. Egg laying occurred between early December 2009 and early February 2010, predominantly when water temperatures fell below $8{ }^{\circ} \mathrm{C}$. All egg masses were laid on aquarium walls within a few centimetres of the water line.

Three egg masses laid in early January were removed for examination through development. Each was left undisturbed for $24 \mathrm{~h}$ after egg laying had ceased before being removed from the aquarium walls and maintained in $1 \mu \mathrm{m}$ filtered seawater at $6{ }^{\circ} \mathrm{C}$. This was close to local water temperatures, which ranged $4.0-8.3{ }^{\circ} \mathrm{C}$ between January and March 2010 (local temperature data obtained bramblemet (www.bramblemet.co.uk/) and CEFAS (www.cefas. defra.gov.uk/our-science/observing-and-modelling/monitor ing-programmes/sea-temperature-and-salinity-trends/presen tation-of-results/station-22-fawley-ps.aspx) databases). Each week 3 capsules were randomly selected and dissected from each egg mass (Fig. 1a). For each egg mass, the outer layer of egg capsules was removed prior to any examination as these are often empty or hold a very small number of eggs. The contents of each capsule were examined, ontogenetic stage was described and eggs or embryos were measured along their longest axis using an eyepiece graticule. When a capsule contained loose eggs, approximately 20 were measured per capsule. When embryos were present of any age, all were measured (on average 9-11). From the trochophore stage and for the duration of nurse egg feeding, 3 capsules per egg mass were examined daily to determine the duration of short ontogenetic stages and the time taken to consume nurse eggs. Each egg mass was also examined non-invasively each week. Transparency of the capsule wall allowed approximate ontogenetic stage to be determined, and the percentage of the mass at each developmental stage was estimated (Fig. 1b). From this, embryonic development was described, including ontogenetic stages, developmental timing, change in embryo size, nurse egg partitioning and intracapsular size differences during development. Ontogenetic stages were defined as egg, trochophore, early veliger, veliger, pediveliger, pre-hatching juvenile and hatching juvenile (see below for descriptions).

Intracapsular contents through development

In order to investigate the intracapsular contents, B. undatum egg masses were collected from Southampton Water
(Southampton, UK, $50^{\circ} 50^{\prime} \mathrm{N}, 001^{\circ} 19^{\prime} \mathrm{W}$ ) from approximately $10 \mathrm{~m}$ water depth between January and March, 2009 and 2010. Seawater temperatures ranged from 4 to $10{ }^{\circ} \mathrm{C}$ during these periods. Collection took place using beam trawls deployed by the University of Southampton research vessel $R V$ Callista. In total, 35 egg masses were collected, all of which were fixed in $4 \%$ formalin for later investigation.

Capsules were selected at random from all $35 \mathrm{egg}$ masses. As above, the outer layer of each egg mass was removed prior to this. Buccinum undatum egg capsules are relatively ellipsoid in shape, with a convex/concave face (Fig. 1a, b). Each capsule was measured in three dimensions (length, width, depth; $\pm 0.01 \mathrm{~mm}$ ) using digital calipers (Absolute digimatic caliper, Mitutoyo (UK) Ltd, Andover, UK). From these measurements, the volume of each egg capsule was estimated using an adaptation of equations used by Pechenik (1983), Rawlings (1990). The following equation was used.

$V=(\pi a b) \times c$

where $a=$ length $/ 2, b=$ width $/ 2$ and $c=$ depth.

Each capsule was then dissected, number of embryos was counted (using a bogorov counting chamber) and ontogenetic stage determined under a compound-microscope. To investigate the relationship between capsule volume and number of eggs or veligers within a capsule, approximately 160 capsules at egg stage (i.e. prior to any development occurring; 15 egg masses; 10-11 capsules from each) and 160 capsules at veliger stage were examined (18 egg masses, 8-9 capsules from each). Capsules ranging from 5.15 to $10.49 \mathrm{~mm}$ length $\left(39.0-287.5 \mathrm{~mm}^{3}\right.$ volume) were compared. Regression analyses were carried out to examine the relationship between capsule volume and number of eggs, and capsule volume and number of veligers.

Change in number of embryos per capsule during development was investigated by examining 100 capsules at veliger stage (12 egg masses, 8-9 capsules from each) and 100 capsules at pre-hatching juvenile stage (9 egg masses, 11-12 capsules from each). Since the number of eggs and embryos per capsule is related to capsule size, for this comparison, capsules of a narrower size range (length 6-8 mm, volume $52.4-146.2 \mathrm{~mm}^{3}$ ) were used. This eliminated the possibility of any change in number of embryos per capsule to be influenced by capsule size. Only veligers containing nurse eggs were counted; it was presumed veligers with no nurse eggs would not develop successfully. An unpaired $t$ test was carried out to compare number of veligers per capsule to number of pre-hatching juveniles per capsule. 

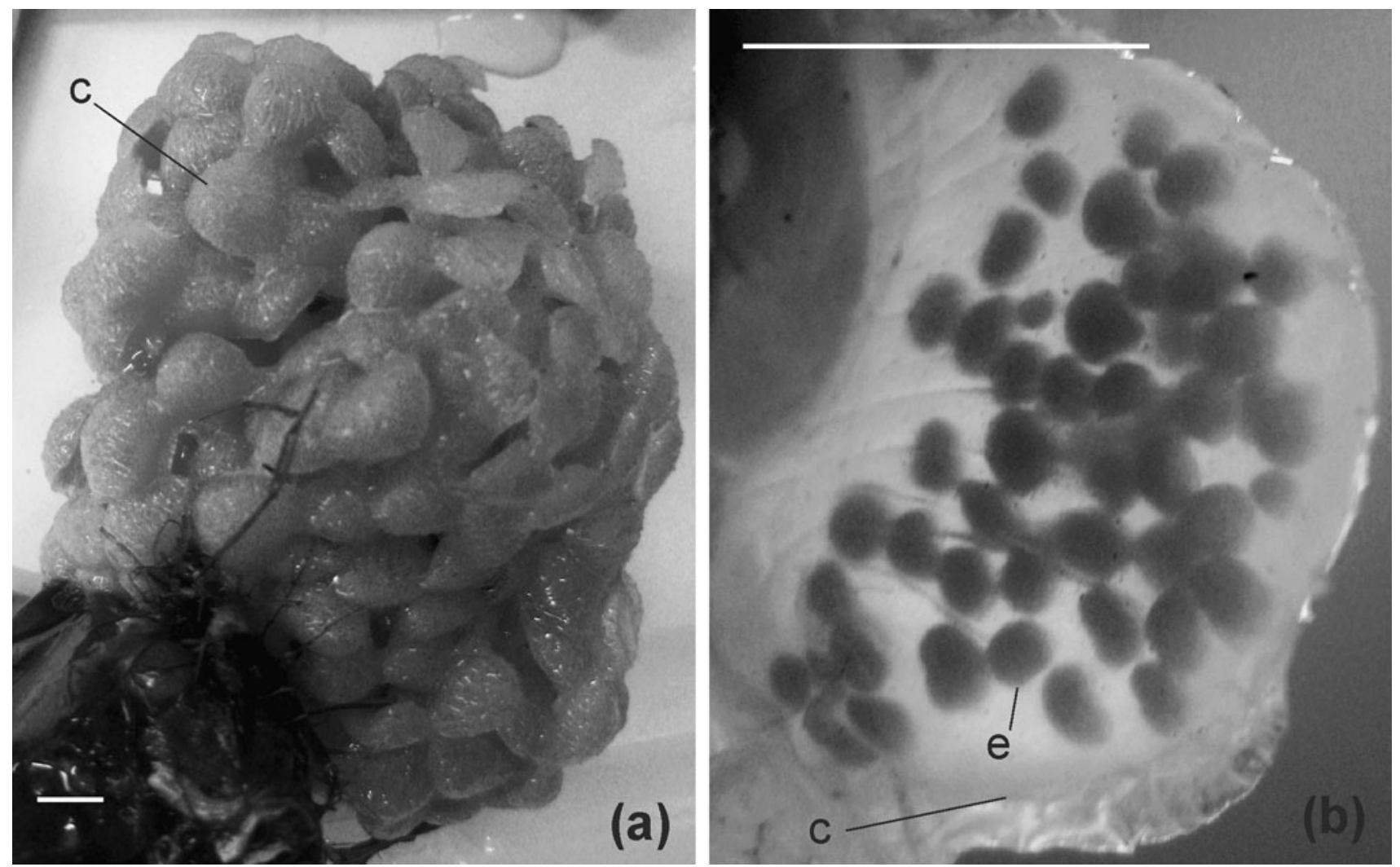

Fig. 1 a Egg mass of B. undatum showing individual capsules. b A large individual egg capsule showing many developed embryos inside, post nurse egg consumption. Scale bars represent $5 \mathrm{~mm}$. $c$ capsule, $e$ embryo

\section{Results}

\section{Ontogenetic stages}

Seven ontogenetic stages were identified. These are described below.

\section{Egg}

Each capsule contains 475-2,639 (mean 1,094) small spherical eggs with no definition. Eggs are cream or yellow in colour and have an average diameter of $234 \mu \mathrm{m}$. Within a capsule, egg diameter varies on average by $36 \mu \mathrm{m}$. Approximately $1 \%$ of these eggs are developing embryos. The remaining are nurse eggs. At this stage, both developing and nurse eggs are identical (Fig. 2a; Table 1). Egg capsules remain at this stage on average for 49 days.

\section{Trochophore}

After 42-56 days developing embryos become globular shaped with a non-circular translucent membrane around the darker embryo. A cilia band (prototroch) is present around approximately one-third to half of the outer circumference of the membrane (Fig. 2b). Each trochophore is a little larger than an egg, with an average length of $321 \mu \mathrm{m}$. Each embryo remains at the trochophore stage for just 2-3 days (Table 1).

\section{Early veliger}

As the early veliger stage is reached, the prototroch extends laterally to form paired velar lobes with marginal cilia around a central simple mouth. Velar lobes are used for collection of eggs and locomotory movement. Each early veliger is mobile but lacks obvious intentional direction. Behind each lobe and just in front of the main body of the early veliger, paired larval kidneys develop, slightly opaque in colour. Whole (generally nurse) eggs are manipulated into the mouth section using the cilia. These are engulfed and stored in the midgut (Portmann 1925), which forms a circular ball directly behind the mouth section, surrounded by a thin outer membrane. There is some asynchrony in the early development of the embryos from individual capsules. In total, between 2 and 35 veligers develop per capsule (average 11). Each embryo consumes nurse eggs for 3-7 days (at $6{ }^{\circ} \mathrm{C}$ ). Total consumption by all embryos within a capsule occurs during the early veliger stage, over 4-10 days. Eggs are not damaged during consumption but are stored in the midgut, conserved for later nutritional use. Whole, 
Fig. 2 Intracapsular developmental stages of B. undatum. (a) Egg, (b) trochophore, (c) early veliger, (d) veliger, (e) pediveliger and (f) prehatching juvenile. $n$ nurse egg or undeveloped embryo, om outer membrane, $c$ cilia, $v l$ velar lobe, $m$ mouth, $m g$ midgut, $m e$ mantle edge, $m c$ mantle cavity, $v m$ visceral mass, $l h$ larval heart, $l k$ larval kidney, $s$ shell, $s i$, siphon, $s g$ siphonal groove, $t$ tentacle, $e$ eye, $f$ foot, $o$ operculum, $s a$ shell apex, $s r$ spiral ribs, ar axial ribs

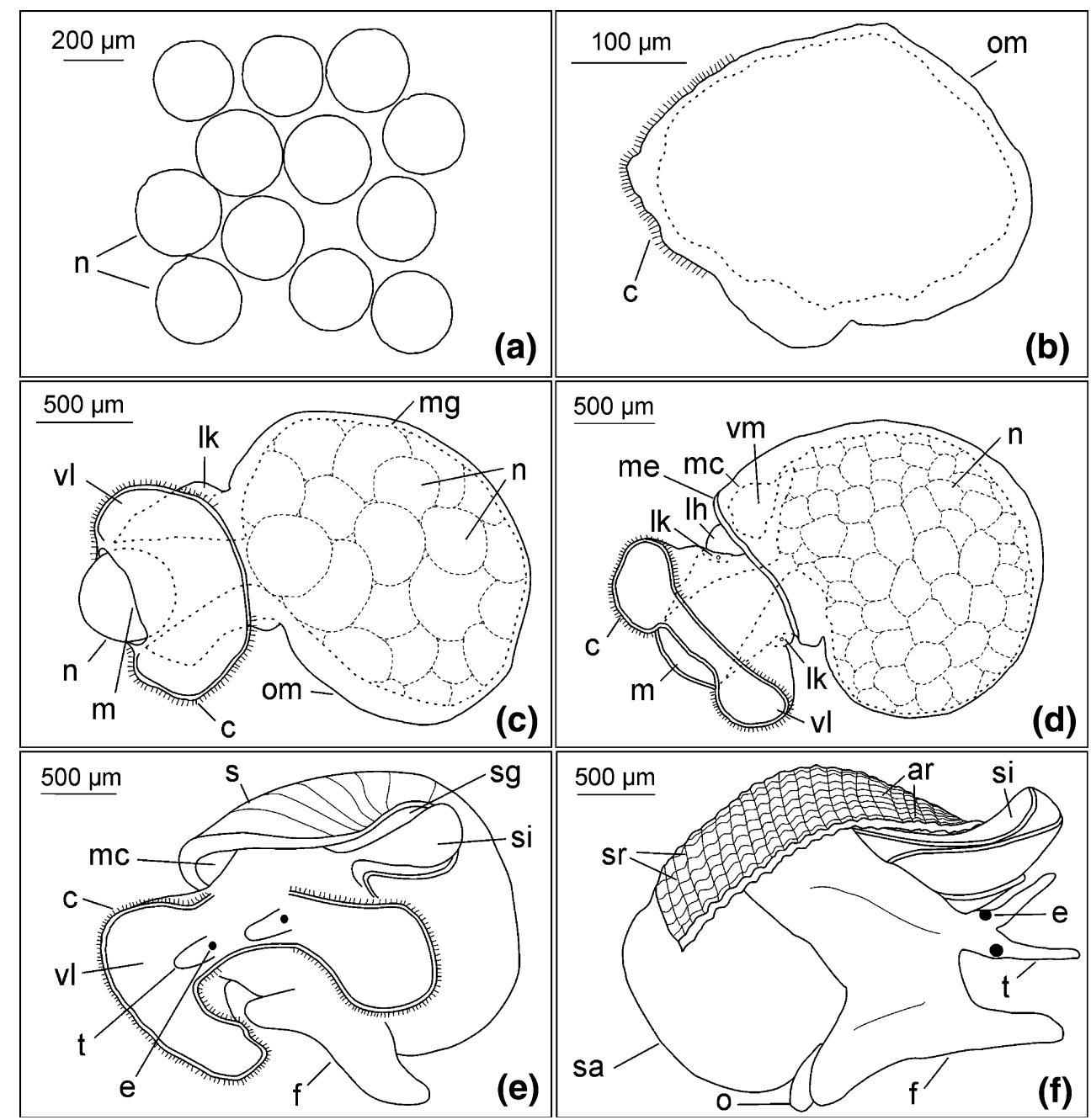

Table 1 Developmental periods for intracapsular development in B. undatum from the south coast of England at $6{ }^{\circ} \mathrm{C}$

\begin{tabular}{|c|c|c|c|c|c|c|}
\hline $\begin{array}{l}\text { Ontogenetic } \\
\text { stage }\end{array}$ & $\begin{array}{l}\text { Mean time in days } \\
\text { spent at each stage } \\
\text { (individual) }\end{array}$ & $\begin{array}{l}\text { Time at developmental } \\
\text { stage in days } \\
\text { (whole egg mass) }\end{array}$ & $\begin{array}{l}\text { Mean size } \\
(\mathrm{mm} \pm \mathrm{SD})\end{array}$ & $\begin{array}{l}\text { Mean size } \\
\text { variation within } \\
\text { one capsule }(\mathrm{mm})^{\mathrm{a}}\end{array}$ & $n$ & $n$ (capsules) \\
\hline Egg & 49 & $0-56$ & $0.23( \pm 0.01)$ & 0.04 & 3,235 & 142 \\
\hline Trochophore & 2 & $42-56$ & $0.32( \pm 0.02)$ & 0.01 & 19 & 12 \\
\hline Early veliger & 5 & $42-56$ & $1.46( \pm 0.15)$ & 0.33 & 121 & 15 \\
\hline Veliger & 18 & $42-77$ & $1.65( \pm 0.17)$ & 0.27 & 97 & 17 \\
\hline Pediveliger & 18 & $70-98$ & $1.91( \pm 0.32)$ & 0.42 & 144 & 20 \\
\hline Pre-hatching juvenile & 44 & $91-140$ & $2.15( \pm 0.29)$ & 0.38 & 74 & 14 \\
\hline Hatching juvenile & $\mathrm{n} / \mathrm{a}$ & $133-140$ & $2.43( \pm 0.39)$ & $\mathrm{n} / \mathrm{a}$ & 102 & $\mathrm{n} / \mathrm{a}$ \\
\hline
\end{tabular}

Mean size at each ontogenetic stage is displayed $(\mathrm{mm})$. Means are determined as an average of $n$ measurements; $n$ dictates total number of individuals measured. $n$ (capsules) dictates number of capsules individuals were measured from and that were examined at each stage. Where $\mathrm{n} / \mathrm{a}$ is stated, value was inapplicable or not determined

${ }^{\text {a }}$ Only capsules with 2 or more individuals included

undamaged nurse eggs can be seen inside the each early veliger. Early veligers average $1.46 \mathrm{~mm}$ across their longest axis. Within one capsule, embryo size may vary by as much as $0.85 \mathrm{~mm}$. These size differences continue to be observed throughout development. Once all nurse eggs are consumed, early veligers, veligers and even pediveligers are 
occasionally found in a capsule, which have consumed no nurse eggs at all (Figs. 1b, 2c, 3a, b; Table 1).

\section{Veliger}

In the veliger, the mantle edge thickens and a thin larval shell becomes visible around the midgut, creating a transparent layer. The midgut appears important in dictating the dimensions of this shell. The velar lobes become more separated, and distinct and the larval kidneys continue to be seen, often with a central yellow spot. The central mouth section becomes more opaque, early foot development begins and no further nurse egg consumption is possible.
The mantle edge and the visceral mass (white in colour) beneath it become obvious. A transparent pulsating membrane located dorsolaterally in front of the mantle edge becomes evident; this is often named the larval heart (Hughes 1990; Khanna and Yadav 2004). Nurse eggs stored beneath the mantle are still clearly individually discernible at this stage and even going into the pediveliger stage (Figs. 2d, 3b, c; Table 1). It is possible to break the mantle or shell on the back of the veliger or pediveliger and find nurse eggs still inside, which are not degraded and have not yet been digested. Embryos remain at the veliger stage for approximately 14-21 days. During this period, development within a capsule becomes synchronised.
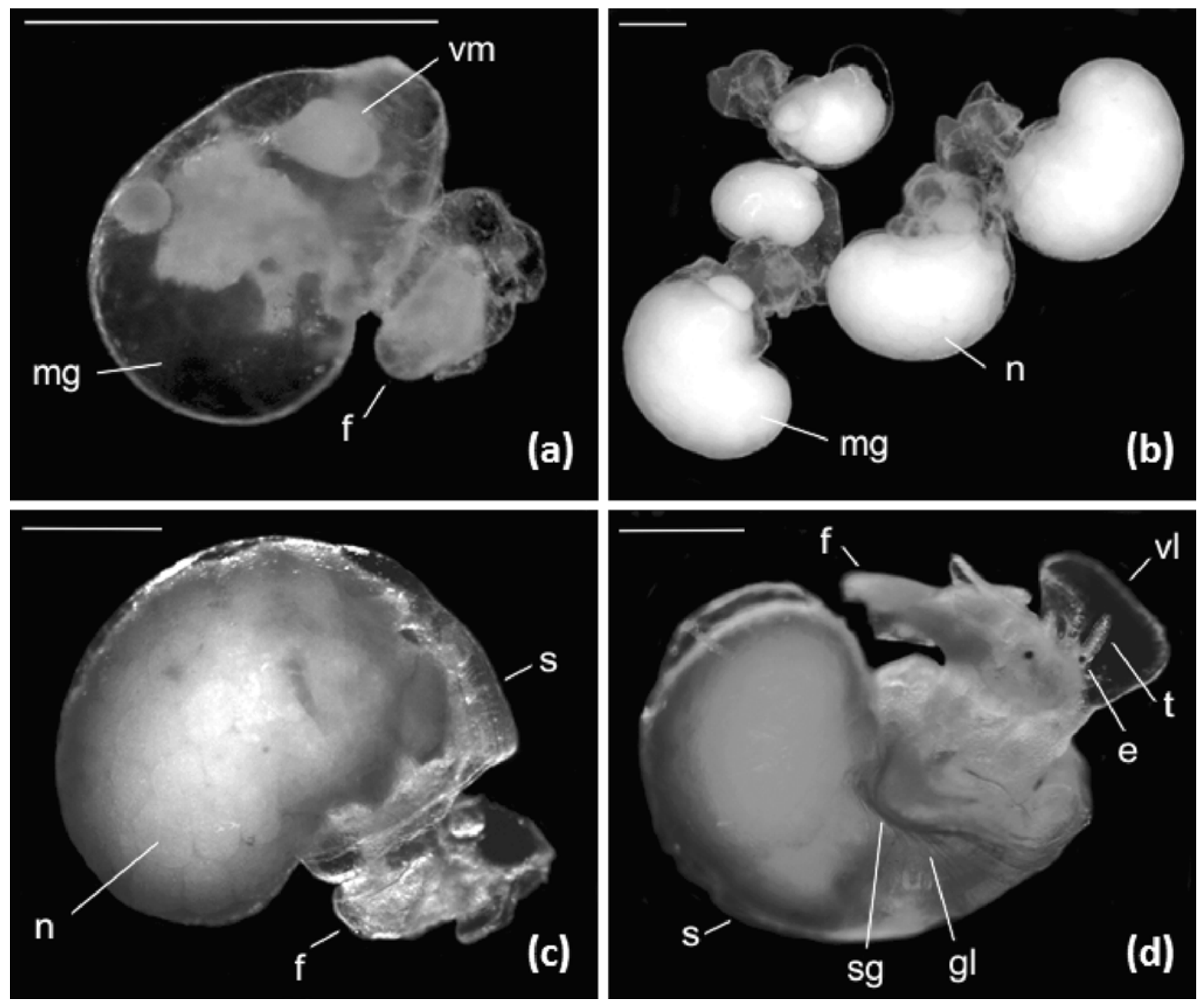

Fig. 3 Early development in B. undatum. (a) Early pediveliger stage with empty midgut indicating few or no nurse eggs were consumed. (b) Veligers of varying sizes developing alongside each other; within one capsule and following nurse egg consumption. (c) Early pediveliger stage with individual nurse eggs still clearly discernible

under the shell. (d) Well-developed mid pediveliger stage with velar lobes still present. Growth lines can be observed on shell. $n$ nurse egg, $v l$ velar lobe, $m g$ midgut, $v m$ visceral mass, $s$ shell, $s g$ siphonal groove, $t$ tentacle, $e$ eye, $f$ foot, $g l$ growth lines. Scale bars represent $500 \mu \mathrm{m}$ 


\section{Pediveliger}

At the pediveliger stage, the shell thickens and becomes increasingly apparent. The mantle cavity is initially visible beneath the mantle edge and the siphonal groove begins to form. The foot, eyes, tentacles and siphon appear. The velum and cilia, which are large at the beginning of this stage, begin to shrink back. They disappear by the end of the pediveliger stage. The larval kidneys and larval heart also disappear. Embryos remain at this stage for approximately 14-21 days (Figs. 2e, 3c, d; Table 1).

\section{Pre-hatching juvenile}

Shell growth continues and spiral and axial ribs begin to develop in the shell as the pre-hatching juvenile stage is reached. The shell thickens and colours brown (becomes pigmented). The first whorl becomes obvious and the shell shape elongates. Head, foot, tentacle and siphon features become more prominent and the operculum appears. The feeding proboscis also develops internally during this time. Pre-hatching juveniles complete development over a further 35-49 days before hatching commences. Pre-hatching juvenile size ranges from 1.57 to $3.06 \mathrm{~mm}$. (Fig. 2f; Table 1).

\section{Hatching juvenile}

The features described for pre-hatching juveniles become more prominent. The juvenile emerges from the egg capsule through an opening created through radular scraping. They remain on the egg mass for a few days before moving off to feed. Overall hatching size ranged from 1.70 to $3.45 \mathrm{~mm}$ (Table 1).

\section{Embryonic development}

Each egg mass took between 9 and 11 days to be laid, with complete intracapsular development taking 133-140 days (19-20 weeks) at $6{ }^{\circ} \mathrm{C}$. Within each egg mass, development was asynchronous by up to 14 days throughout the developmental period. Within each capsule, development was initially asynchronous; both trochophore and early veliger stages, and early veliger and veliger stages were observed together in capsules. By late veliger stage development within a capsule was synchronous. Following an initial increase in embryo size as nurse egg consumption occurred, individual size (measured as change in length) increased at a steady rate throughout the remainder of the encapsulated period (Figs. 4, 5; Table 1). Within each capsule, large size differences were observed between embryos at all stages of development. Whole, undamaged nurse eggs were visible inside embryos throughout the veliger and pediveliger stages. Occasional early veligers, veligers and pediveligers

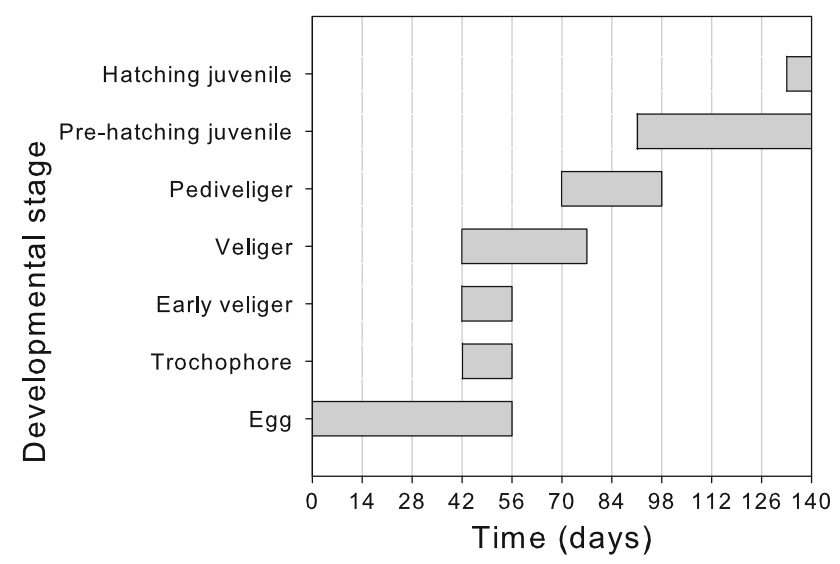

Fig. 4 Developmental time (days) for B. undatum from Southampton Water (UK) at $6{ }^{\circ} \mathrm{C}$. Times shown represent development across whole egg masses

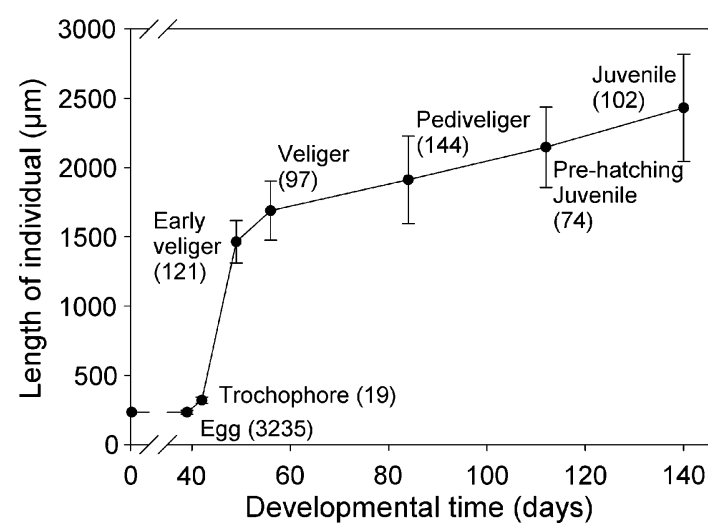

Fig. 5 Change in size of individuals (measured as length along longest axis) during intracapsular development. Size displayed is average length of individual at each stage in $\mu \mathrm{m}$. Nurse egg consumption occurs between trochophore and early veliger stages. The average size displayed for early veliger is taken post nurse egg consumption. Error bars indicate $\pm 1 \mathrm{SD}$

were found, which had not consumed any nurse eggs. Apart from the absence of nurse eggs, these embryos were completely normal in their development (Fig. 3a-c; Table 1).

Intracapsular contents through development

\section{Relationship between capsule volume and number of embryos per capsule}

Egg capsule volume ranged from 39.0 to $287.5 \mathrm{~mm}^{3}$ (capsule length 5.15-10.49 mm). Overall, number of eggs per capsule averaged 1,094 and number of veligers per capsule averaged 11. Regression analysis showed there to be a significant relationship between capsule volume and number of eggs $\left(r^{2}=0.7646 ; p<0.001\right)$, and capsule volume and number of veligers $\left(r^{2}=0.5615 ; p<0.001\right)$. As a percentage of total eggs, on average $1 \%$, develop into veligers (Fig. 6a, b). 

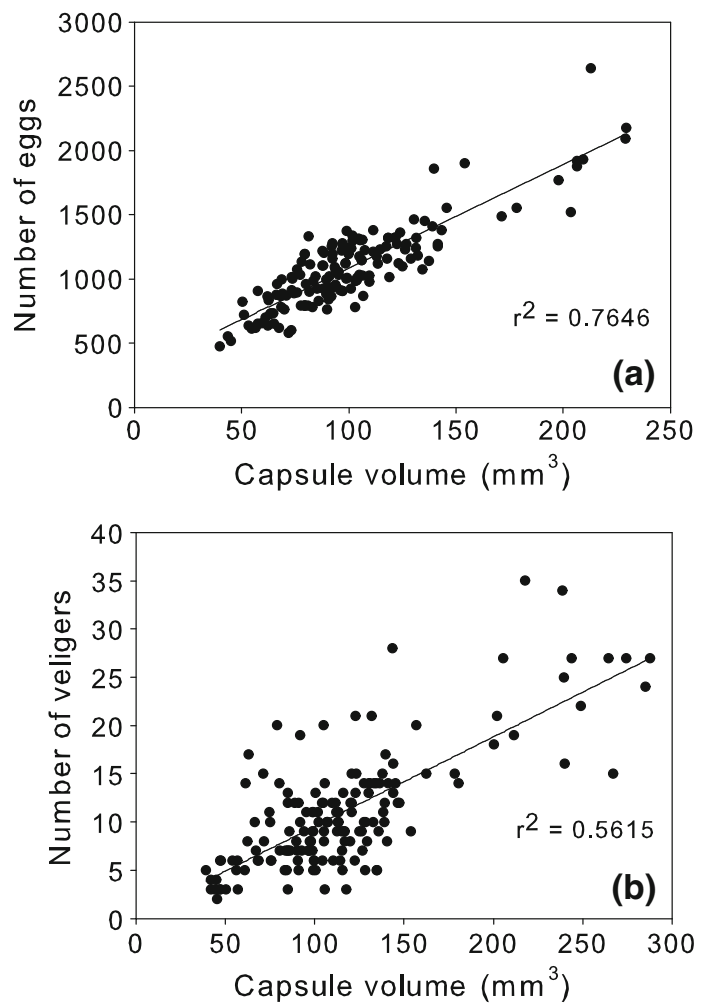

Fig. 6 Relationship between capsule volume and (a) number of eggs, (b) number of veligers in egg masses of B. undatum. Both relationships are significant to $p<0.001$. The $r^{2}$ values are displayed

\section{Change in number of embryos per capsule through development}

When examining capsules ranging from 6 to $8 \mathrm{~mm}$ in length (volume 52.4-146.2 $\mathrm{mm}^{3}$ ), number of developing veligers per capsule ranged from 3 to 21 (average 9) and number of pre-hatching juveniles per capsule ranged from 2 to 20 (average 9). An unpaired $t$ test showed there to be no difference between the two groups $(p=0.772)$.

\section{Discussion}

Embryonic development and intracapsular contents data

The distribution of $B$. undatum extends from the southern coast of the UK, northwards up into the North Atlantic and Arctic oceans, across a temperature range of -1.5 to $22{ }^{\circ} \mathrm{C}$ (Bramblemet; CEFAS; Martel et al. 1986a). For the population used in the present study, annual temperatures vary seasonally from approximately $4-22{ }^{\circ} \mathrm{C}$, and egg laying and development normally occur in water temperatures ranging $4-10{ }^{\circ} \mathrm{C}$. With temperatures maintained at $6{ }^{\circ} \mathrm{C}$, the duration of intracapsular development (4.5-5 months) was similar to previous estimates of $B$. undatum development in British waters (Kideys et al. 1993; Valentinsson 2002). Longer and shorter periods have been reported across the species distribution (e.g. Martel et al. 1986a; Nasution 2003). The observed differences in duration of development can be attributed to the known effects of temperature on metabolic rates in ectotherms.

In the present study, the number of eggs per capsule averaged 1,094 and the number of developing veligers averaged 11. While egg numbers were similar to those indicated in previous studies (Table 2), veliger numbers were similar to figures reported by Hancock (1967), but lower than other estimates (Portmann 1925; Martel et al. 1986a). Since number of veligers is often significantly related to capsule volume (Gallardo 1979; Pechenik et al. 1984; Valentinsson 2002), it is likely that larger capsules were examined in the latter studies. Results indicate approximately $1 \%$ of eggs developed, giving a ratio of 109 nurse eggs per embryo, almost identical to the 110 eggs per embryo reported by Portmann (1925). The percentage of eggs developing was also comparative to other previous estimates for B. undatum (Martel et al. 1986a; Valentinsson 2002; Nasution 2003). Similar results have been reported for other buccinids including 1.1-2\% for Buccinum isaotakki (Ilano et al. 2004), 0.2-1.8\% for Buccinum cyaneum (Miloslavich and Dufresne 1994) and $1 \%$ for Colus stimpsoni (West 1979).

Past studies provide conflicting views on the occurrence of intracapsular cannibalism in B. undatum (Table 2). Portmann (1925) indicated a reduction in number of individuals per capsule during development (from early veligers to veligers and pre-hatching juveniles), which was suggested to be due to cannibalism (Fretter and Graham 1985). Contrary to this, other studies have shown the number of developing embryos per capsule to remain constant during development, indicating no cannibalism (Hancock 1967; Martel et al. 1986a). Our results were in agreement with these latter studies. Similarly, no cannibalism during development was reported in the buccinids B. cyaneum (Miloslavich and Dufresne 1994) and B. isaotakki (Ilano et al. 2004), and only very rarely was it observed in the buccinid L. dirum (Rivest 1983). It has, however, been reported in some other gastropods including Crucibulum quiriquinae (Véliz et al. 2001), Crepidula coquimbensis (Véliz et al. 2003; Brante et al. 2009) Trophon geversianus (Cumplido et al. 2011) and a vermetid gastropod (Strathmann and Strathmann 2006).

Capsule size or volume has previously been shown to be a good indicator of number of eggs and veligers within a capsule. In the current study, these figures were both significantly related to capsule volume. Number of eggs was more closely related to volume than number of veligers, suggesting eggs are more regularly distributed amongst 


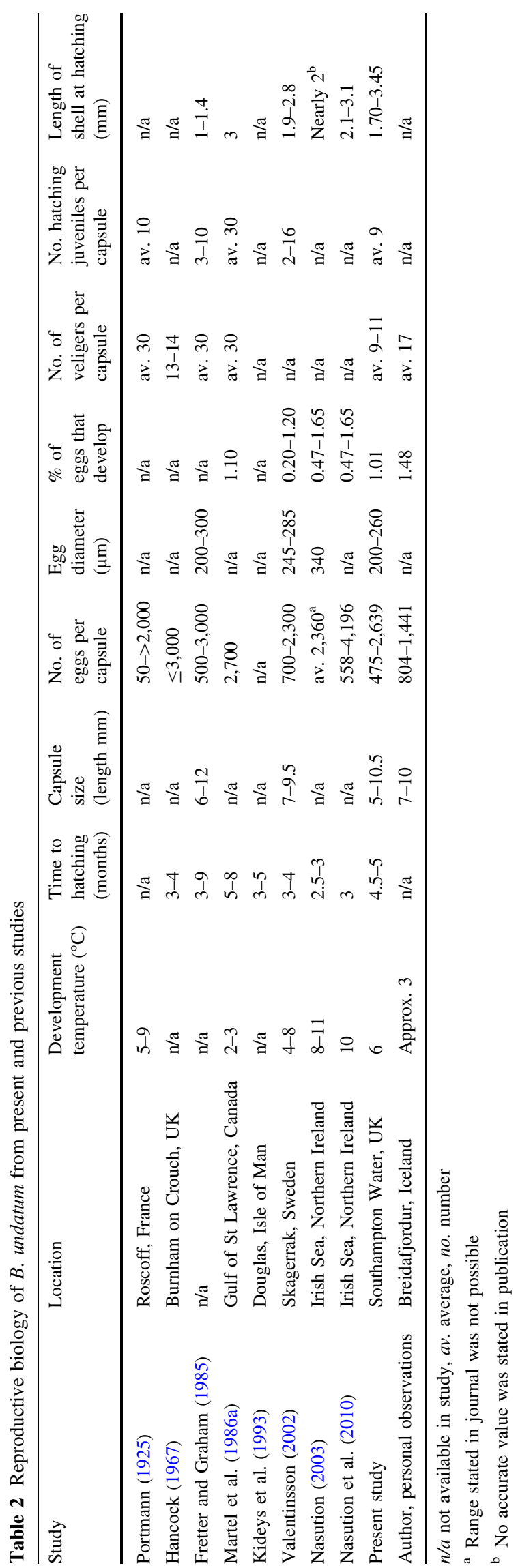

capsules than are developing embryos. This pattern has been reported before for both B. undatum (Valentinsson 2002; Nasution et al. 2010) and other gastropods, including B. cyaneum (Miloslavich and Dufresne 1994), B. isaotakki (Ilano et al. 2004), Hexaplex (Trunculariopsis) trunculus (Lahbib et al. 2010), Acanthina monodon (Gallardo 1979), Nucella lapillus (Pechenik et al. 1984) and Nucella lamellosa (Spight 1976b). Contrary to this, number of eggs has been found to be related to, but number of veligers to be independent of capsule size in the buccinid $L$. dirum (Rivest 1983), the calyptraeid Crepipatella dilatata (Chaparro et al. 1999) and the muricid Nucella ostrina (Lloyd and Gosselin 2007).

An initial rapid increase in embryo size was observed at the early veliger stage in the present investigation. This was followed by a relatively linear increase in size for the remainder of intracapsular development. Similar changes in size during development have been reported for B. cyaneum (Miloslavich and Dufresne 1994) and B. isaotakki (Ilano et al. 2004). For both, however, the initial increase was slower than was observed in this investigation. In B. isaotakki, it is likely that this is reflective of the slower nurse egg consumption rate previously observed in this species (Ilano et al. 2004). Probably, nurse eggs are also taken up at a slower rate in B. cyaneum.

Previous hatching sizes for $B$. undatum have been reported ranging from 1.0 to $3.1 \mathrm{~mm}$ (e.g. Fretter and Graham 1985; Nasution et al. 2010). These are similar to hatching sizes observed in the present investigation, which averaged just below $2.5 \mathrm{~mm}$ in length.

Nurse egg partitioning

Life history theories suggest parental fitness is maximised by investing equally into all offspring (Smith and Fretwell 1974). Traditionally, resource partitioning (in the form of nurse eggs) during intracapsular development follows this trend. Embryos compete for nurse eggs, but within a capsule competitiveness is normally equal. As a result, nurse eggs are consumed quite evenly by all embryos. This does not mean hatchlings are always of a similar size; within one species, or even one clutch, the ratio of nurse eggs to developing embryo may vary greatly between capsules, resulting in large differences in offspring size. This is usually believed to be due to irregular distribution of embryos amongst capsules (Thorson 1950; Rivest 1983; Spight 1976a; Miloslavich and Dufresne 1994). Within a capsule however, generally only small differences in offspring size are reported. For example, Spight (1976a) examined 2 species of muricid gastropod (Nucella emarginata and A. spirata) and found that although embryo size varied considerably between capsules, within a capsule large differences were rare. Previous studies 
Table 3 Periods of development and nurse egg consumption times for different species of gastropods

\begin{tabular}{|c|c|c|c|c|c|}
\hline Species & Temperature $\left({ }^{\circ} \mathrm{C}\right)$ & $\begin{array}{l}\text { Duration of } \\
\text { intracapsular } \\
\text { development } \\
\text { (days) }^{\mathrm{a}}\end{array}$ & $\begin{array}{l}\text { Duration of } \\
\text { nurse egg } \\
\text { consumption } \\
\text { (days) }^{\mathrm{a}}\end{array}$ & $\begin{array}{l}\text { Percentage of } \\
\text { development over } \\
\text { which nurse eggs } \\
\text { are consumed }(\%)\end{array}$ & Authors \\
\hline B. isaotakii & $2.5-10.2$ & 200 & 40 & 20 & Ilano et al. (2004) \\
\hline B. undatum & $8-11$ & 70 & 28 & 40 & Nasution (2003) \\
\hline B. undatum & 6 & $133-140$ & $3-7$ & $2-5$ & Present study \\
\hline C. dilatata & 17 & $18-26$ & Up to 26 & 100 & Chaparro and Paschke (1990) \\
\hline $\begin{array}{l}\text { Hexaplex } \\
\quad \text { (Trunculariopsis) } \\
\text { trunculus }\end{array}$ & $22-24$ & 49 & 35 & 71 & Lahbib et al. (2010) \\
\hline L. dirum & 12 & $84-98$ & $7-21$ & $8-20$ & Rivest (1983) \\
\hline T. geversianus & $12-14$ & 112 & 38 & 34 & Cumplido et al. (2011) \\
\hline
\end{tabular}

All species included are direct developers

${ }^{\text {a }}$ Some timings have been converted from weeks stated in original study

examining development in B. undatum have indicated similar results, and comparable observations have also been reported for the gastropods $L$. dirum (Rivest 1983) and C. dilatata (Chaparro and Paschke 1990; Chaparro et al. 1999). In contrast, the present study found nurse egg partitioning to be quite different to that previously described for $B$. undatum or other buccinids. Large size differences were continually observed between embryos from any one capsule, and regularly individuals were found alongside a capsulemate four times their size (Fig. 3b). Although to our knowledge, variations in nurse egg consumption have not previously been reported in other buccinids, such intracapsular differences have been described for a small number of gastropods, predominantly from the muricidae family. These include A. monodon (Gallardo 1979), Chorus giganteus (González and Gallardo 1999) and T. geversianus (Cumplido et al. 2011). In A. monodon and $C$. giganteus, intracapsular size differences continue to be evident at hatching, presumed to be related to earlier nurse egg consumption (Gallardo 1979; González and Gallardo 1999). In T. geversianus, sibling cannibalism (which can also affect offspring size) occurs during later developmental stages, and it is not clear whether hatching sizes vary (Cumplido et al. 2011).

It is widely assumed that offspring quality increases with size (e.g. Thorson 1950; Spight 1976a; Rivest 1983; Gosselin and Rehak 2007; Lloyd and Gosselin 2007; Przeslawski 2011). Larger hatchlings are less likely to be affected by factors such as physical stress, predation and starvation. While intracapsular size differences are generally believed to be due to competition (Gallardo 1979; González and Gallardo 1999), in the present investigation, they are probably enhanced by a combination of asynchrony in development and short nurse egg consumption periods. We found nurse egg feeding to be very rapid, with each early veliger consuming eggs for just $3-7$ days. This relates to $2-5 \%$ of the developmental period. In comparison, in most gastropods, nurse egg consumption occurs over a large proportion of intracapsular development (Table 3). Even the shortest uptake periods previously reported (8-20\% of the developmental period) (Rivest 1983) are still more than double the length of the consumption period observed by us. Within a capsule, the potential to take up nurse eggs is limited by the amount already consumed by earlier developers. Thus, while intracapsular asynchrony in early development is not uncommon (e.g. Vasconcelos et al. 2004; Fernández et al. 2006; Lahbib et al. 2010), when it is combined with the short nurse egg consumption period seen in $B$. undatum, it follows that even a 24-h lag in initial embryonic development will put individuals at a distinct disadvantage. Rapid nurse egg consumption in $B$. undatum is consistent with findings by Portmann (1925), but contradictory to those of Nasution (2003). Additionally, $6{ }^{\circ} \mathrm{C}$ is towards the lower end of the temperature range that southern populations of $B$. undatum naturally develop in. Nurse egg consumption is even faster at warmer temperatures (Authors, unpublished data). This may lead to larger intracapsular size differences during development, and with predicted sea temperature elevations, intracapsular size ranges may increase.

Normal veligers and pediveligers that had not successfully consumed any nurse eggs were occasionally found within a capsule in the present investigation (Fig. 3a). It is likely that these individuals reached the feeding stage after all resources had been consumed. Since no further feeding occurs between nurse egg consumption and hatching, these embryos had no nutrition available to them for development and we assumed they did not survive. This in itself is very unusual and even in the few reported cases of large intracapsular size differences between embryos (Gallardo 1979; 
González and Gallardo 1999; Cumplido et al. 2011), to our knowledge completely 'empty' embryos have not been observed.

In the current study, it was noted that for several weeks following consumption, individual nurse eggs could still be observed through the thin veliger mantle and early shell (Fig. 3c). Throughout this period, if the mantle or shell was broken, whole eggs would spill out. This indicated that although eggs were rapidly consumed, they were not immediately utilised but instead were stored for later nutritional use. This phenomenon was also noted by Portmann (1925), who recognised that nurse eggs stayed intact inside B. undatum veligers for long periods of time. In comparison, he found they disintegrated directly after consumption in $N$. lapillus. Nurse eggs have also been shown to be visible internally throughout the feeding period in A. monodon (Gallardo 1979), L. dirum (Rivest 1983) and $C$. dilatata (Chaparro and Paschke 1990). In each case however, the literature suggests nurse eggs begin to be assimilated shortly following consumption. In other species such as $T$. geversianus, nurse eggs break down prior to consumption by embryos (Cumplido et al. 2011).

The range in size of embryos within a capsule and the occurrence of 'empty' embryos observed in this investigation indicates that a higher level of competition is occurring in B. undatum than is normally observed during intracapsular development in gastropods. While large intracapsular size differences have been observed in some muricid gastropods, to our knowledge, competition for nurse eggs to the degree that some embryos are left with no nutrition for development has never previously been reported.

Acknowledgments Thanks are given to the skipper and crew of $R V$ Callista for their help with sample collection. This work was supported by grants from the Total Foundation (Abyss2100) to ST and the Malacological Society to KS.

\section{References}

Bayne CJ (1968) Histochemical studies on the egg capsules of eight gastropod molluscs. Proc Malacol Soc Lond 38:199-212

Brante A, Fernández M, Viard F (2009) Limiting factors to encapsulation: the combined effects of dissolved protein and oxygen availability on embryonic growth and survival of species with contrasting feeding strategies. J Exp Biol 212:2287-2295

Chaparro OR, Paschke KA (1990) Nurse egg feeding and energy balance in embryos of Crepidula dilatata (Gastropoda: Calyptraeidae) during intracapsular development. Mar Ecol Prog Ser 65:183-191

Chaparro OR, Oyarzun RF, Vergara AM, Thompson RJ (1999) Energy investment in nurse eggs and egg capsules in Crepidula dilatata Lamarck (Gastropoda, Calyptraeidae) and its influence on the hatching size of the juvenile. J Exp Mar Biol Ecol 232:261-274

Cumplido M, Pappalardo P, Fernández M, Averbuj A, Bigatti G (2011) Embryonic development, feeding and intracapsular oxygen availability in Trophon geversianus (Gastropoda: Muricidae). J Moll Stud 77:429-436

D'Asaro CN (1970) Egg capsules of prosobranch mollusks from south Florida and the Bahamas and notes on spawning in the laboratory. Bull Mar Sci 20:414-440

Fernández M, Pappalardo P, Jeno K (2006) The effects of temperature and oxygen availability on intracapsular development of Acanthina monodon (Gastropoda: Muricidae). Rev Chile Hist Nat 79:155-167

Fretter V, Graham A (1985) The prosobranch molluscs of Britain and Denmark. Part 8. Neogastropoda. J Moll Stud [Suppl] 15: 435-556

Gallardo CS (1979) Developmental pattern and adaptations for reproduction in Nucella crassilabrum and other muricacean gastropods. Biol Bull 157:453-463

González KA, Gallardo CS (1999) Embryonic and larval development of the muricid snail Chorus giganteus (Lesson 1829) with an assessment of the developmental nutrition source. Ophelia 51:77-92

Gosselin LA, Rehak R (2007) Initial juvenile size and environmental severity: the influence of predation and wave exposure on hatching size in Nucella ostrina. Mar Ecol Prog Ser 339: 143-155

Hancock DA (1967) Whelks. MAFF Laboratory Leaflet No. 15. Fisheries Laboratory, Burnham-upon-Crouch, Essex

Hughes RN (1990) Larval development of Morum oniscus (L.) (Gastropoda: Harpidae). J Moll Stud 56:1-8

Ilano AS, Fujinaga K, Nakao S (2004) Mating, development and effects of female size on offspring number and size in the neogastropod Buccinum isaotakii (Kira, 1959). J Moll Stud 70:277-282

Khanna DR, Yadav PR (2004) Biology of mollusca. Discovery Publishing House, Delhi

Kideys AE, Nash RDM, Hartnoll RG (1993) Reproductive cycle and energetic cost of reproduction of the neogastropod Buccinum undatum in the Irish Sea. J Mar Biol Assoc UK 73:391-403

Lahbib Y, Abidli S, Trigui El, Menif N (2010) Laboratory studies of the intracapsular development and juvenile growth of the banded murex, Hexaplex trunculus. J World Aquac Soc 41:18-34

Lloyd MJ, Gosselin LA (2007) Role of maternal provisioning in controlling interpopulation variation in hatching size in the marine snail Nucella ostrina. Biol Bull 213:316-324

Martel A, Larrivee DH, Himmelman JH (1986a) Behavior and timing of copulation and egg-laying in the neogastropod Buccinum undatum. J Exp Mar Biol Ecol 96:27-42

Martel A, Larrivee DH, Klein KR, Himmelman JH (1986b) Reproductive cycle and seasonal feeding activity of the neogastropod Buccinum undatum. Mar Biol 92:211-222

Miloslavich P, Dufresne L (1994) Development and effect of female size of egg and juvenile production in the neogastropod Buccinum cyaneum from the Saguenay Fjord. Can J Fish Aquat Sci 51:2866-2872

Moran AL (1999) Intracapsular feeding by embryos of the gastropod genus Littorina. Biol Bull 196:229-244

Morel GM, Bossy SF (2004) Assessment of the whelk (Buccinum undatum L.) population around the Island of Jersey, Channel Isles. Fish Res 68:283-291

Nasution S (2003) Intra-capsular development in marine gastropod Buccinum undatum (Linnaeous 1758). J Nat Indones 5:124-128

Nasution S, Roberts D (2004) Laboratory trials on the effects of different diets on growth and survival of the common whelk, Buccinum undatum L. 1758, as a candidate species for aquaculture. Aquac Int 12:509-521

Nasution S, Roberts D, Farnsworth K, Parker GA, Elwood RW (2010) Maternal effects on offspring size and packaging constraints in the whelk. J Zool 281:112-117 
Natarajan AV (1957) Studies on the egg masses and larval development of some prosobranchs from the Gulf of Mannar and the Palk Bay. Proc Indian Acad Sci 46:170-228

Ojeda JA, Chaparro OR (2004) Morphological, gravimetric, and biochemical changes in Crepidula fecunda (Gastropoda: Calyptraeidae) egg capsule walls during embryonic development. Mar Biol 144:263-269

Pechenik JA (1979) Role of encapsulation in invertebrate life histories. Am Nat 114:859-870

Pechenik JA (1983) Egg capsules of Nucella lapillus (L.) protect against low-salinity stress. J Exp Mar Biol Ecol 71:165-179

Pechenik JA (1999) On the advantages and disadvantages of larval stages in benthic marine invertebrate life cycles. Mar Ecol Prog Ser 177:269-297

Pechenik JA, Chang SC, Lord A (1984) Encapsulated development of the marine prosobranch gastropod Nucella lapillus. Mar Biol $78: 223-229$

Portmann A (1925) Der Einfluss der Nahreier auf die LarvenEntwicklung von Buccinum und Purpura. Z Morphol Okol Tiere 3:526-541

Przeslawski R (2011) Notes on the egg capsule and variable embryonic development of Nerita melanotragus (Gastropoda: Neritidae). Moll Res 31:152-158

Rawlings TA (1990) Associations between egg capsule morphology and predation among populations of the marine gastropod, Nucella emarginata. Biol Bull 179:312-325

Rawlings TA (1995) Direct observation of encapsulated development in muricid gastropods. Veliger 38:54-60

Rawlings TA (1999) Adaptations to physical stresses in the intertidal zone: the egg capsules of neogastropod molluscs. Am Zool 39:230-243

Rivest BR (1983) Development and the influence of nurse egg allotment on hatching size in Searlesia dira (Reeve, 1846) (Prosobranchia: Buccinidae). J Exp Mar Biol Ecol 69:217-241

Rosenberg G (2009) A database of Western Atlantic marine mollusca. Malacol 4.1.1 URL http://www.malacolog.org/

Smith CC, Fretwell SD (1974) The optimal balance between size and number of offspring. Am Nat 108:499-506
Spight TM (1976a) Ecology of hatching size for marine snails. Oecologia 24:283-294

Spight TM (1976b) Hatching size and the distribution of nurse eggs among prosobranch embryos. Biol Bull 150:491-499

Stöckmann-Bosbach R (1988) Early stages of the encapsulated development of Nucella lapillus (Linnaeus) (Gastropoda, Muricidae). J Moll Stud 54:181-196

Strathmann RR (1985) Feeding and nonfeeding larval development and life-history evolution in marine invertebrates. Ann Rev Ecol Syst 16:339-361

Strathmann MF, Strathmann RR (2006) A vermetid gastropod with complex intracapsular cannibalism of nurse eggs and sibling larvae and a high potential for invasion. Pac Sci 60:97-108

Thorson G (1950) Reproductive and larval ecology of marine bottom invertebrates. Biol Rev 25:1-45

Valentinsson D (2002) Reproductive cycle and maternal effects on offspring size and number in the neogastropod Buccinum undatum (L.). Mar Biol 140:1139-1147

Valentinsson D, Sjödin F, Jonsson PR, Nilsson P, Wheatley C (1999) Appraisal of the potential for a future fishery on whelks (Buccinum undatum) in Swedish waters: CPUE and biological aspects. Fish Res 42:215-227

Vasconcelos P, Gaspar MB, Joaquim S, Matias D, Castro M (2004) Spawning of Hexaplex (Trunculariopsis) trunculus (Gastropoda: Muricidae) in the laboratory: description of spawning behavior, egg masses, embryonic development, hatchling and juvenile growth rates. Invertebr Rep Biol 46:125-138

Véliz D, Guisado C, Winkler FM (2001) Morphological, reproductive, and genetic variability among three populations of Crucibulum quiriquinae (Gastropoda: Calyptraeidae) in northern Chile. Mar Biol 139:527-534

Véliz D, Winkler FM, Guisado C (2003) Development and genetic evidence for the existence of three morphologically cryptic species of Crepidula in northern Chile. Mar Biol 143:131-142

West DL (1979) Nutritive egg determination in Colus stimpsoni (Prosobranchia: Buccinidae). Am Zool 19:851-1015 